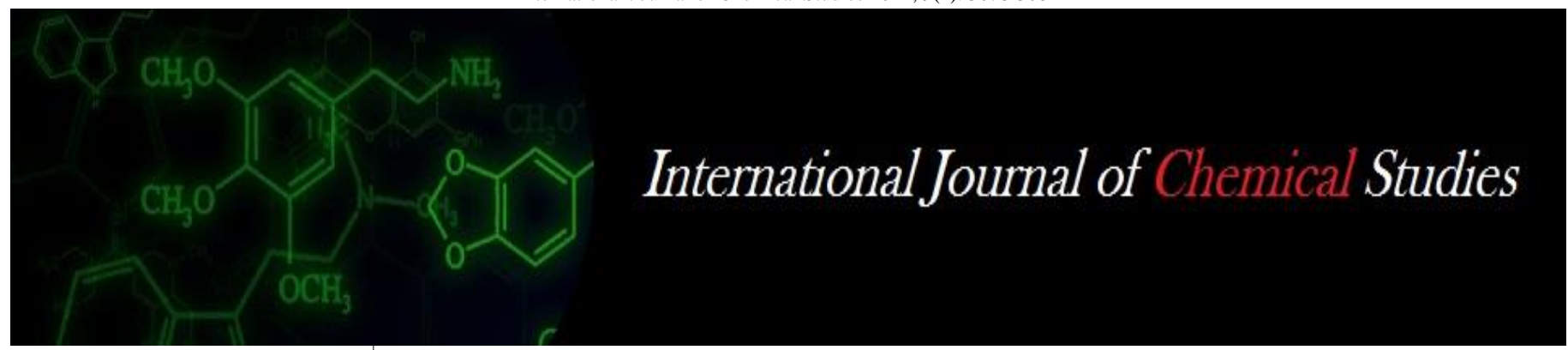

P-ISSN: 2349-8528

E-ISSN: 2321-4902

www.chemijournal.com

IJCS 2021; 9(1): 3078-3082

(C) 2021 IJCS

Received: 08-11-2020

Accepted: 20-12-2020

Sandeep Kumar Maurya

M.Sc. Agricultur, Department of

Agronomy, Institute of

Agricultural Sciences, Banaras

Hindu University, Varanasi,

Uttar Pradesh, India

RK Singh

Professor and Coordinator, SAP

(UGC) Department of

Agronomy, Institute of

Agricultural Sciences, Banaras

Hindu University, Varanasi,

Uttar Pradesh, India

\section{Brijesh Kumar}

Research Scholar, Department of

Agronomy, National Dairy

Research Institute, Karnal,

Haryana, India

Sarvajeet

Research Scholar, Department of Soil science and Agricultural

Chemistry, Institute of

Agricultural Sciences, Banaras

Hindu University, Varanasi,

Uttar Pradesh, India

Ranvir

M.Sc. Agricultur, Department of Agronomy, Navsari Agriculture

University, Navsari, Gujarat,

India

Corresponding Author: Brijesh Kumar

Research Scholar, Department of Agronomy, National Dairy

Research Institute, Karnal,

Haryana, India

\section{A review on Partial root-zone drying (PRD): A modern irrigation technique}

\author{
Sandeep Kumar Maurya, RK Singh, Brijesh Kumar, Sarvajeet and Ranvir
}

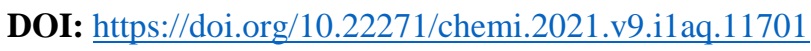

\begin{abstract}
Field experiments were conducted for 3 years from 2000 to 2002 to assess proportional crop yield differences obtained under conventional deficit irrigation (CDI) and partial root-zone irrigation (PRI) practices, compared with full irrigation (FULL) where plant water requirements were fully met. The experimental crops included vegetables (tomato and pepper), field crops (maize and cotton) and citrus. The fruit yield of greenhouse-grown tomato with FULL irrigation was higher than with PRI (7-22\% lower) but was not significantly different. The PRD irrigation is a novel improvement of deficit irrigation in which half of the root zone is irrigated alternatively in scheduled irrigation events. In the last decade, scientists across the world, especially from arid to semi-arid countries, have extensively evaluated this irrigation as a water-saving irrigation strategy on agronomic and horticultural plants. This review paper focuses on the physiological and morphological aspects of PRD on plants and its ultimate impact on yield and water productivity. Overall, under limited water resources where water is precious, PRD is a viable irrigation option to increase water productivity while margining the yield, rather than only increasing the economic yield without concerning the value of water in limited water environments.
\end{abstract}

Keywords: Partial root-zone drying irrigation, Full irrigation, Water productivity, Field crops, Vegetables

\section{Introduction}

Irrigated agriculture plays a major role in food production. About $70 \%$ of the total water withdrawals and $60-80 \%$ of total consumptive water use are consumed in irrigation (Huffaker and Hamilton, 2007). That time day by day increase in food demand and decrease in water resources that should be resolved. When The irrigated area should be increased by more than $20 \%$ and the irrigated crop yield should be increased by $40 \%$ by 2025 to secure the food for 8 billion people (Lascano and Sojka, 2007) ${ }^{[22]}$. In the Mediterranean areas, due to climate change, the frequency and severity of prolonged periods of drought, as well as strong seasonal variation in the water budget, are predicted. The PRD irrigation is a novel improvement of deficit irrigation in which half of the root zone is irrigated alternatively in scheduled irrigation events. is partial root-zone drying (PRD), which consists of the exposure of half of the root system to alternate drying and wetting cycles. Theoretically, roots of the watered side of soil will keep a favorable plant status, while dehydration of the other side will promote the synthesis of abscisic acid (ABA), which will reach leaves by the transpiration stream and further reduce stomatal conductance. Water-saving irrigations are used to improve water productivity (WP) in recent years. Deficit irrigation (DI) and partial root-zone drying irrigation (PRD) are the water-saving irrigation methods that cut down irrigation amounts of full irrigation to crops. The amounts of irrigation reduction are crop-dependent and generally accompanied by no or minor yield loss that increases the water productivity (Ahmadi et al., 2010b) ${ }^{[2]}$. PRD practice has been successfully tested on a range of crops, especially tree crops, including apples, passion fruit, grapevines, oak, birch and olive trees. The results from several studies showed that crops under PRD yielded better than under DI when the same amount of water is applied, indicating higher water use efficiency (WUE) and even better fruit quality. Overall, under limited water resources where water is precious, PRD is successful irrigation compared to FI that can save irrigation water up to $50 \%$ without significant yield loss, while may improve the yield quality. During PRD, soil drying is expected to stimulate root to leaf biochemical signaling that reduces stomatal conductance and transpiration. 
PRD is thought to reduce plant water consumption by enhancing abscisic acid production in the dry half of the roots (Stoll et al., 2000) ${ }^{[11]}$. A hormonal signal that reduces the stomatal aperture and thus transpiration of the leaves (Davies et al., 2000) ${ }^{[7]}$. Water use efficiency (WUE) is increased because the well-watered half of the root-zone ensures the maintenance of fruit growth, while vegetative growth is reduced (Dry et al., 2000) ${ }^{[11]}$. The effect of water stress on plants at physiological, biochemical and molecular levels a crop that is imposed to PRD as a water-saving irrigation may show diverse responses to water stress in terms of these three responses levels according to the severity and timing of the water stress. However, in this review article much is focused on the effects of water stress at the physiological and morphological levels which play important roles in regulation of crop reproductive development, which directly relate to quantitative and qualitative properties of yield (Liu et al., 2005) ${ }^{[23]}$.

\section{Water-saving irrigation techniques}

Availability of water in crop production is becoming a major limiting factor. Therefore, it is necessary to adopt watersaving irrigation techniques. Water-saving irrigations are used to improve water productivity (WP). There is two types of water-saving irrigation techniques.

- Deficit irrigation

- Partial root-zone drying technique of irrigation

\section{Deficit irrigation}

"Deficit irrigation (DI) is an optimization strategy whereby net returns are maximized by reducing the amount of irrigation water. in which irrigation is applied during droughtsensitive growth stages of a crop. DI maximizes irrigation water productivity, which is the main limiting factor (English, 1990) ${ }^{[12]}$. In other words, DI aims at stabilizing yields and at obtaining maximum crop water productivity rather than maximum yields (Zhang and Davies, 1989) ${ }^{[43] . "}$

\section{Partial root-zone drying technique of irrigation}

Partial root-zone drying (PRD) is a modified form of deficit irrigation (DI) (English et al., 1990) ${ }^{[12]}$, which involves irrigating only one part of the root zone in each irrigation event, leaving another part to dry. Therefore, PRD is a novel irrigation strategy since half of the roots are placed in drying soil and the other half is growing in irrigated soil (Ahmadi et al., 2010a) ${ }^{[2]}$. PRD includes such practices that may increase irrigation-water-use efficiency (IWUE) and thereby reduction in irrigation water requirement, which would have utmost importance in water-scarce regions.

Development of Partial Rootzone Drying (PRD) Irrigation Originally, the concept of PRD was first applied by Grimes et al. (1968) ${ }^{[17]}$ in the USA on-field cotton in alternate furrow irrigation and then followed by Sepaskhah et al. (1976), Sepaskhah and Amin-Sichani (1976), and Samadi and Sepaskhah (1984) [33, 29] on beans through surface and subsurface drip irrigations in Iran. Later on, some extensive studies on PRD were conducted in Australia and the PRD term was used and developed for grapevines (Loveys et al., 2000; Kriedmann and Goodwin, 2003) ${ }^{[26,21]}$.

\section{PRD in practice}

\section{Increasing water productivity}

In the literature, the term "water use efficiency" (WUE) is interchangeably used for crop yield per unit evapotranspiration. In this article, "water productivity" (WP) is defined as crop yield per unit applied irrigation water that is looking into the efficiency of applied irrigation water (Zhang, 2003) [42]. Partial stomatal closure and reduced leaf area occurred due to increased [ABA]. These are the main physiological responses to decrease transpiration in plants under PRD and enhance WP (Davies et al., 2002) ${ }^{[8]}$. The relationship between $A_{n}$ and $g_{s}$ is intrinsic water use efficiency. It is clear that at mild water stress a large reduction in $g_{s}$ is coupled with a negligible effect on $A_{n}$. This means that a decrease in $\mathrm{g}_{\mathrm{s}}$ resulted in a large reduction in transpiration, while the photosynthesis rate is not greatly affected. Therefore, a higher WP (or WUE) is obtained (Morison et al., 2008) ${ }^{[27]}$ and it is crucial to study the $A_{n}$ and $g_{s}$ when WP or WUE is of interest.

\section{Experimental studies on PRD}

Significant water-saving coupled with the economic yield has been documented by Ahmadi (2009) ${ }^{[1]}$ in a review of greenhouse and field studies on the application of PRD on different species of trees and annual crops. Different experimental results in PRD have shown that irrigation water may be reduced by approximately $30-50 \%$ in PRD with no significant yield reduction. In some case, even better fruit quality was obtained in PRD (e.g., Kirda et al., (2004) ${ }^{[19]}$. The most investigations on PRD have initiated in the last decade and, however, practical development of the technique continues for agronomical and horticultural crops (Morison et $a l ., 2008)^{[27]}$. The list of literature on experimental studies on PRD is exhaustive; however, the following subsections include, but are not limited to, a relatively complete and broad list of diverse crop species on which the PRD has been applied in the last decade.

\section{Field crops \\ Sugar beet and Sugarcane}

Alternate or every other furrow irrigation is considered as PRD irrigation. Every-other furrow irrigation resulted in an average of $18 \%$ reduction in sugar beet root yield with an average of $34 \%$ reduction in applied water at customized 10 day irrigation intervals. De la Hera et al. (2007) ${ }^{[9]}$ indicated that duration and the timing for the application of PRD should be determined according to the crop, soil, and site specifications. In this case (sugar beet as a vegetative crop), shorter irrigation intervals may play a key role in the effectiveness of PRD. Therefore, Sepaskhah and Kamgar Haghighi (1997) ${ }^{[31]}$ studied the effects of the every-other furrow and every-furrow irrigation on yield and WP of sugar beet at different irrigation intervals of 6,10 , and 14 days. They indicated that every-other furrow irrigation at 10- day irrigation intervals used a smaller amount of irrigation water, however, some root yield reduction occurred. On the other hand, every-other furrow irrigation at 6-day intervals reduced irrigation water by $23 \%$ with a similar yield to that of everyfurrow irrigation at 10-day intervals.

\section{Sorghum}

Every-other furrow irrigation (PRD) in the semi-arid region of Iran resulted in an average of $28 \%$ reduction in sorghum grain yield (reproductive crop) with a similar reduction in applied water at customized 15-day irrigation intervals (Sepaskhah and Ghasemi, 2008) ${ }^{[30]}$. They studied the effects of an everyother furrow, and every-furrow irrigations on grain yield and WP of grain sorghum at different irrigation intervals of 10 , 15 , and 20 days. It was indicated that every-other furrow 
irrigation at 10-day intervals of every-other furrow reduced the applied water by $11 \%$ with no yield reduction compared with every-furrow irrigation at 15-day intervals.

\section{Maize}

Every-other furrow irrigation (PRD) in a semi-arid region resulted in an average of $28 \%$ reduction in maize grain yield (reproductive crop and highly sensitive to water stress) with an average of $31 \%$ reduction in applied water at customized 7-day irrigation intervals (Sepaskhah and Khajehabdollahi, 2005) ${ }^{[32]}$. They studied the effects of the every-other furrow and every-furrow irrigations on maize grain yield and WP at different irrigation intervals of 4,7 , and 10 days. It was indicated that every-other furrow irrigation at 4-day intervals of every-other furrow reduced the applied water by $6 \%$ with no grain yield reduction compared with every-furrow irrigation at 7-day intervals.

Kang et al. (2000a) ${ }^{[18]}$ also applied PRD in irrigated maize in an arid region in China. Irrigation was applied to furrow in three ways: alternate furrow irrigation (AFI), fixed furrow irrigation (FFI), and conventional furrow irrigation (CFI). Each irrigation method was further divided into three treatments with different irrigation amounts (45, 30, 22.5 $\mathrm{mm})$. Furthermore, AFI maintained high grain yields coupled with a $50 \%$ reduction in the amount of irrigation water, while FFI and CFI both revealed a substantial reduction in yield with reduced irrigation water.

\section{Vegetable crops \\ Potato}

The effects of PRD on physiological responses of potatoes in greenhouse and field conditions were studied by Liu et al. (2006a). In the greenhouse the treatments were FI, and PRD, while in field irrigation, treatments were drip-irrigated to near field capacity (FI) or using $70 \%$ of FI on alternate sides. In a field experiment, PRD resulted in higher intrinsic WUE than in FI. The PRD treatment reduced water use by $30 \%$ and therefore increased WUE by $60 \%$, and no significant reduction in tuber yield

\section{Tomato}

Kirda et al. (2004) ${ }^{[19]}$ applied PRD on greenhouse processing tomatoes and depicted that PRD reduced up to 50\% of irrigation water with a marginal yield reduction. They indicated that in PRD leaf area index and vegetative growth was reduced, therefore, photosynthetic assimilates transferred to fruit growth. Zegbe et al. (2004) ${ }^{[40]}$ conducted a similar study on processing tomatoes using full irrigation (FI) and $50 \%$ of FI irrigation water applied as PRD. They showed that the fruit yields were the same for the treatments, but WUE for PRD plants were $70 \%$ higher than that obtained for FI plots.

\section{Greenhouse experiments}

A drip irrigation system with two laterals laid down along the plant rows was used for irrigation of greenhouse-grown crops, pepper, and tomato. The two laterals with drippers spaced at $100 \mathrm{~cm}$ were arranged in such a way that there was always one dripper centered between the two plants but installed alternately on the two separate laterals. Tomato and pepper were transplanted on 23 February 2000, as spring-planted crops. In the following season, 2000/01, only tomato transplanted on 3 November 2000 was investigated as a fallplanted vegetable crop. Irrigation water requirement was based on evaporation data recorded from a class-A pan located in the center of the greenhouse. Irrigation water applied to FULL treatment changed from 30 to $125 \%$ of cumulative evaporation during the growing season. We had used fixed irrigation intervals, 7 days until mid-season (91 and 169 days after transplanting for spring-planted and fallplanted crops, respectively), then two irrigations applied weekly, at 3-day and 4-day intervals. Depending on the treatment, we had the option of applying irrigation water through either a single lateral or the two laterals. For irrigation of FULL and CDI treatments, water was applied using the two laterals concurrently, so that all sides of the plant roots were wetted similarly, except that the CDI treatment received a reduced amount of water. Applying water through only a single lateral, as required with PRI treatments, resulted in wetting of only one-half of the plant root zone. Switching the opened laterals used during irrigation changed the wetted halves of the roots. Experimental plots of each treatment for both pepper and tomato had three rows of 21 plants, with a row spacing of $80 \mathrm{~cm}$ and planting space of $50 \mathrm{~cm}$ in rows. Fruit yields of 19 plants of the central row, excluding the two plants at extreme ends, were recorded during harvest.

The greenhouse was heated for frost protection only when needed to prevent temperatures below 5LC. Fertilizers were applied continuously with irrigation water at concentrations of 100,30 and $150 \mathrm{mg} \mathrm{L}^{21}$ of $\mathrm{N}, \mathrm{P}$ and $\mathrm{K}$, respectively, for the FULL treatment. The nutrient concentrations were adjusted for other treatments in proportion to the percentage reduction in applied water to ensure that all the treatments received the same amount of fertilizer. The forms of the fertilizers used were urea, phosphoric acid, and potassium sulfate for nitrogen, phosphorus and potassium, respectively.

\section{Conclusions}

Partial root-zone drying irrigation (PRD) is the novel deficit irrigation strategy that is generally adopted in the last decade to a vast kind of agronomic and horticultural crops to increase water productivity (WP). This paper generally reviewed the most recent studies on PRD. Results from diverse crop species showed that in comparison to the traditional deficit irrigation strategy (DI) that the crop is subjected to some degree of water stress, PRD is successfully alternative irrigation compared to FI that can save irrigation water up to approximately $50 \%$ without significant yield loss, while may improve the yield quality. However, the amount of saved irrigation water and improved WP strongly depends on the crop, soil, and site specifications. Moreover, cumulative results revealed that PRD could not be effective in reproductive crops that are sensitive to water stress. In such cases the recommended strategy is that irrigation events should be more frequent and supplementary full irrigation should be applied in sensitive phonological periods of crop growth. Since PRD is newly applied to some tree species, it is recommended to do more studies on different kinds of trees in different environmental conditions. Therefore, PRD is recommended for the irrigation of farms and gardens in arid and semi-arid areas that are suffering from a lack of freshwater resources for agricultural production. PRD practices can be a viable and advantageous option compared with full irrigation to prevent crop yield reduction when and if there is a water shortage or to improve crop quality. It is noteworthy that studies on PRD are continuing and in the future new results will be available from other crop species, probably from horticultural and tree crops with a high irrigation water requirement. 


\section{References}

1. Ahmadi SH, Andersen MN, Plauborg F, Poulsen RT and Hansen S. A quantitative approach to developing more mechanistic gas exchange models for field grown potato: A new insight into chemical and hydraulic signalling. Agri. and Forest Meteorology 2009;149:1541-1551.

2. Ahmadi SH, Andersen MN, Plauborg F, Poulsen RT, Jensen CR, Sepaskhah AR and Hansen S. Effects of irrigation strategies and soils on field grown potatoes: Yield and water productivity. Agri. Water Management. 2010b.

3. Ahmadi SH, Andersen MN, Plauborg F, Poulsen RT, Jensen CR, Sepaskhah AR, et al. Effects of irrigation strategies and soils on field grown potatoes: Gas exchange and xylem [ABA]. Agri. Water Management 2010;97:1486-1494.

4. Ahmadi SH, Andersen MN, Plauborg F, Poulsen RT, Jensen CR, Sepaskhah AR, et al. Effects of irrigation strategies and soils on field grown potatoes: Gas exchange and xylem [ABA]. Agric. Water Manag 2010; 97:1486-1494. [CrossRef]

5. Benjamin JG, Nielsen DC. Water deficit effects on root distribution of soybean, field pea and chickpea. Field Crops Research 2006;97248-253.

6. Centritto M, Wahbi S, Serraj R, Chaves MM. Effects of partial root zone drying (PRD) on adult olive tree (Olea europaea) in field conditions under arid climate. II. Photosynthetic responses. Agric. Ecosyst. Environ 2005; 106:303-311. [CrossRef]

7. Davies WJ, Bacon MA, Thompson DS, Sobeih W, Rodriguez LG. J. Exp. Bot. 2000;51:1617-1626.

8. Davies WJ, Wilkinson S, Loveys BR. Stomatal control by chemical signaling and the exploitation of this mechanism to increase water use efficiency in agriculture. New phytologist 2002;153:449-460.

9. De la Hera, ML, Romero P, Gomez-Plaza E, Martinez A. Is partial root-zone drying an effective irrigation technique to improve water use efficiency and fruit quality in field-grown wine grapes under semiarid conditions? Agri. Water Management 2007;87:261-274.

10. De Souza CR, Maroco JP, dos Santos TP, Rodrigues ML, Lopes C, Pereira JS, Chaves MM. Control of stomatal aperture and carbon uptake by deficit irrigation in two grapevine cultivars. Agric. Ecosyst. Environ 2005;106: 261-274. [CrossRef]

11. Dry PR, Loveys BR, Stoll M, Steward D, McCarthy MG. Australian Grapegrower Winemaker 2000;438:35-39.

12. English MJ, Musick JT, Murty VVN. Deficit irrigation. In: Management of farm irrigation systems (Hoffman, G.J., Howell, T.A., and Solomon, K.H., Fereres, E., Soriano, M.A., 2007. Deficit irrigation for reducing agricultural water use. Jour. of Experimental Botany, 1990;58:147-159.

13. Ferrarin C, Zaggia L, Paschini E, Scirocco T, Lorenzetti $\mathrm{G}$, Bajo $\mathrm{M}$, et al. Hydrological regime and renewal capacity of the micro-tidal Lesina Lagoon, Italy. Estuar. Coast. 2014; 37:79-93. [CrossRef]

14. Fort C, Fauveau ML, Muller F, Label P, Granier A, Dreyer E. Stomatal conductance, growth and root signalling in young oak seedlings subjected to partial soil drying. Tree Physiol 1997;17:281-289. [CrossRef] [PubMed]

15. Fort C, Muller F, Label P, Granier A, Dreyer E. Stomatal conductance, growth and root signalling in Betula pendula seedlings subjected to partial soil drying. Tree Physiol 1998;18:769-776. [CrossRef] [PubMed]

16. Gowing DJ, Davies WJ, Jones HG. A positive rootsourced signal as an indicator of soil drying in apple, Malus x domestica Borkh. J. Exp. Bot 1990;41:15351540. [CrossRef]

17. Grimes DW, Walhood VT, Dickens WL. Alternatefurrow irrigation for San Joaquin valley cotton.California Agri 1968;22:4-6.

18. Kang SZ, Liang ZS, Pan YH, Shi PZ, Zhang JH. Alternate furrow irrigation for maize production in an arid area. Agri. Water Management 2000a;45:267-274.

19. Kirda C, Cetin M, Dasgan Y, Topcu S, Kaman H, Ekici B, Derici MR, Ozguven AI. Yield response of greenhouse grown tomato to partial root drying and conventional deficit irrigation. Agri. Water Management 2004;69:191-201.

20. Kirda C, Topcu S, Cetin M, Dasgan HY, Kaman H, Topaloglu F, Ekici B. Prospects of partial root zone irrigation for increasing irrigation water use efficiency of major crops in the Mediterranean region. Annals of Applied Biology 2007;150(3):281-291.

21. Kriedmann PE, Goodwin I. Regulated deficit irrigation and partial rootzone drying. Irrigation insights no.4, Land and Water Australia, Canberra 2003, 102.

22. Lascano RJ, Sojka RE. Preface. In: Irrigation of agricultural crops. $2^{\text {nd }}$ edition, Agronomy Monograph no. 30. ASA-CSSA-SSSA publishing 2007, 664.

23. Liu F, Jensen CR, Shahnazari A, Andersen MN, Jacobsen SE. ABA regulated stomatal control and photo synthetic water use efficiency of potato (Solanum tuberosum L.) during progressive soil drying. Plant Sci 2005;168:831836.

24. Liu F, Shahnazari A, Andersen MN, Jacobsen SE, Jensen CR. Physiological responses of potato (Solanum tubersum L.) to partial root-zone drying: ABA signaling, leaf gas exchange, and water use efficiency. Jour. of Experimental Botany 2006;57:3727-3735.

25. Lovelli S, Perniola M, Scalcione E, Troccoli A, Ziska LH. Future climate change in the Mediterranean area: Implications for water use and weed management. Ital. J. Agron 2012;7:44-49. [CrossRef]

26. Loveys BR, Stoll M, Dry PR, McCarthy MG. Using plant physiology to improve the water use efficiency of horticultural crops. Acta Horticulturae 2000;537:187197.

27. Morison JIL, Baker NR, Mullineaux PM, Davies WJ. Improving water use in crop production.Philosophical Transactions of the Royal Society (London) B 2008;363: 639-658.

28. Samadi A, Sepaskhah AR. Effects of alternate furrow irrigation on yield and water use efficiency of dry beans. Iran Agric. Research, 1984;3:95-115.

29. Sepaskhah AR, Ahmadi SH. A review on partial rootzone drying irrigation. International Journal of Plant Production, 2012;4(4):241-258.

30. Sepaskhah AR, Ghasemi MM. Every-other furrow irrigation with different irrigation intervals for sorghum. Pakistan Journal of Biological Science 2008;11(9):12341239.

31. Sepaskhah AR, Kamgar-Haghighi AA. Water use and yields of sugarbeet grown under every-other-furrow irrigation with different irrigation intervals. Agri. Water Management 1997;34:71-79. 
32. Sepaskhah AR, Khajehabdollahi MH. Alternate furrow irrigation with different irrigation intervals for maize (Zea mays L.). Plant Production Science 2005;8:592-600.

33. Sepaskhah AR, Sichani SA. Evaluation of subsurface irrigation spacings for bean production. Canadian Agricultural Engineering 1976;18:23-26.

34. Sepaskhah AR, Ahmadi SH. A review on partial rootzone drying irrigation. Int. J. Plant Prod 2010;4,241-258. [CrossRef]

35. Songsri P, Jogloy S, Vorasoot N, Akkasaeng C, Patanothai A, Holbrook CC. Root distribution of droughtresistant peanut genotypes in response to drought. Jour. of Agro. and Crop Science 2008;194:92-103.

36. Stoll M, Loveys BR, Dry PR. Hormonal changes induced by partial rootzone of irrigated grapevine. Exp. Bot 2000;51:1627-1634.

37. Turner DW, Menzel CM, Simpson DR. Short-term drying of half the root system reduces growth but not water status or photosynthesis in leaves of passionfruit (Passiflora sp.). Sci. Hortic 1996;65:25-36. [CrossRef]

38. Ventrella D, Giglio L, Charfeddine M, Lopez R, Castellini M, Sollitto D et al. Climate change impact on crop rotations of winter durum wheat and tomato in Southern Italy: Yield analysis and soil fertility. Ital. J. Agron 2012;7:100-108. [CrossRef

39. Wahbi S, Wakrim R, Aganchich B, Tahi H, Serraj R. Effects of partial rootzone drying (PRD) on adult olive tree (Olea europaea) in field conditions under arid climate. I. Physiological and agronomic responses. Agric. Ecosyst. Environ 2005;106:289-301. [CrossRef]

40. Zegbe JA, Behboudian MH, Clothier BE. Partial rootzone drying is a feasible option for irrigating processing tomatoes. Agri. Water Management 2004;68: 195-206.

41. Zegbe JA, Behbouidan MH, Clothier BE. Responses of 'Petopride' processing tomato to partial rootzone drying at different phenological stages. Irrig. Sci 2006;24:203210. [CrossRef]

42. Zhang H. Improving water productivity through deficit irrigation: Examples from Syria, the north China Plain and Oregon, USA. In: Water Productivity in Agriculture: Limits and Opportunities for Improvement (Kijne, J.W., Barker, R., and Molden, D. eds). CABI publishing, 2003, 332.

43. Zhang J, Davies WJ. Sequential responses of whole plant water relations towards prolonged soil drying and mediation by xylem sap ABA concentrations in the regulation of stomatal behaviour of sunflower plants. New Phytol 1989;1113:167-174. 